\title{
VOCATIONAL EDUCATION AND TRAINING POLICIES: THE TENSION BETWEEN INCLUSION, EMPLOYABILITY AND DEMOCRATIZATION ${ }^{1}$
}

\author{
N. Alves ${ }^{1}$, A. J. Almeida ${ }^{2}$, R. Queiroga ${ }^{1}$, P. Guimarães ${ }^{1}$ \\ ${ }^{1}$ Education Institute, University of Lisbon (PORTUGAL) \\ ${ }^{2}$ College of Business Administration, Polytechnic Institute of Setubal (PORTUGAL)
}

\begin{abstract}
This communication is part of the research project YOUNG_ADULLLT ${ }^{2}$. The purpose of this project is to understand the interaction between lifelong learning policies, the life conditions and stages of young adults in situations of vulnerability, and the promotion of social development and inclusion. This communication focuses on the analysis of double certification education and training (VET) provisions (Apprenticeship courses, Professional courses and Adult VET courses), promoted either by regular and Professional schools or public training centres, in the sub-region of the Alentejo Litoral, in Portugal. The analysis of legal frameworks and interviews reveals a tension between three mains aims: the fight against exclusion, the promotion of individual employability and the democratization of school access and success. However, the hegemonic resonant discourse is strongly anchored in a technical-instrumental perspective of education and training, oriented towards employability, and the management of human resources according to the labor market needs.
\end{abstract}

Keywords: Apprenticeship Courses, Professional courses, Adult vocational education and training courses, inclusion, democratization, employability

\section{INTRODUCTION}

Lifelong learning policies (LLL) in general and VET policies in particular are shaped by complex social interactions between policy-makers, firms, civil society representatives and young adults themselves. These interactions constitute the social field where these policies are designed and implemented, and moreover, where their eventual impacts take place. The analysis of the double certification VET provisions (Apprenticeship courses, Professional courses and Adult VET courses) is based on the theoretical framework of cultural political economy (CPE) ([1], [2], [3]). CPE brings together contributions from the critical political economy and the critical analysis of discourse to analyse social formations, such as policies. CPE is based on two main assumptions: the need social actors have to complexity reduction and the role of meaning-making and structuration in order to turn unstructured into structured complexity [1]. It also highlights the fact that policies respond to particular interpretations of the problems and explanations of their causes by presenting specific solutions. In the decision-making process, social actors, namely policy makers and policy actors, attribute different meanings to the problems they are dealing with and choose the solutions according to particular interpretations of the problems. CPE focus on these particular interpretations conveyed through policy discourses, and economic and political imaginaries ${ }^{3}$, their transformation into hegemonic strategies and their institutionalization into specific structures and practices.

According to Jessop [2] all institutional transformations can be explained by the interaction of material and semiotic factors through the mechanisms of variation, selection, retention, and reinforcement. Variation refers to the process by which dominant policy discourses or practices are revisited due to

\footnotetext{
1 Libro de Actas del 6th International Congress of Educational Sciences and Development / coord. por Tamara Ramiro Sánchez, María Teresa Ramiro Sánchez, María Paz Bermúdez Sánchez, 2018, ISBN 978-84-09-02091-1

2 The project YOUNG ADULLLT, Policies Supporting Young People in their Transitions to Adulthood. A Comparative Perspective of Lifelong Learning and Inclusion in Education and Work in Europe, is funded by EU Horizon 2020 (Ref. Young-32015, grant agreement 693167).
}

${ }^{3}$ According to Jessop [2], imaginaries are semiotic systems that structure the unstructured world complexity and/or inform collective interpretation about the world. 
the need to adapt to semiotic or material changes. Selection implies the adoption of particular discourses for interpreting social problems and legitimizing the solutions. Retention refers to the institutionalization and integration of resonant discourses into institutional rules, organizational practices, regulatory frameworks and governance technologies. The greater the range of sites in which the resonant discourses are retained the greater is the probability of their institutionalization and integration in durable compromises. Reinforcement favors dominant resonant discourses and associated practices and filters alternative ones, eliminating them.

\section{METHODOLOGY}

This paper explores the discourses concerning VET provisions in the legal framework and the social actors' ones (local providers and street-level professionals). The adoption of CPE theoretical framework allows us to critically discuss the resonant discourses that supports the creation and implementation of these provisions, their orientations and objectives, the way in which their targetgroup is constructed, and the effects on the life courses of young adults.

The data and analyses presented in this paper derive from a research project - YOUNG_ADULLLT funded by European Union's Horizon 2020 research and innovation programme. The research was conducted in the region of Alentejo Litoral, located southwest of Portugal.

The analysis is supported by an empirical corpus consisting of a set of legal documents and semistructured interviews. In total, 7 interviews were conducted: 4 local managers and 3 street-level professionals (teachers / trainers and psychologist) were interviewed.

\section{RESULTS}

\subsection{VET Policies discourses and aims}

Apprenticeship Courses, Professional Courses and Adult Vocational Education and Training Courses are long term policy measures, run by the State and they all deliver an academic certification and a professional qualification. They are all funded by European Social Fund (ESF) and have been recently integrated in the Youth Guarantee Programme. The three policies under analysis share the same underlying assumption: the improvement of young adults' employability through vocational education and training and curricular internships as the best strategy to fight unemployment. At the same time all of them contribute to what was considered, in the recent past, one of the greatest national goals: to increase the level of academic qualification of the Portuguese population. According to these reasons, the golden rule of these policies is double certification (academic and professional), and the 'unofficial' policy orientation is to guide towards a vocational education and training provision the unemployed low academic achievers, beneficiaries of guaranteed social income, early school leavers (ESL), people not in employment, education or training situation (NEET) and young people at risk of dropping out. In Alentejo Litoral these three vocational education and training provisions are the most important LLL policies young adults can access.

Apprenticeship courses were the first to be created when the vocational education and training in Portugal was rebuilt in the mid-1980s. At the time of its creation in 1984, the main policy objective was to fight against youth unemployment, explained by the lack of professional qualifications, low school attainment and dropout, before the completion of compulsory schooling of 6 years, at the time. During this period, as during the recent financial crisis, the hegemonic discourse explained the high rates of youth unemployment on the basis of young people's skills gap. The alternative discourses that attributed unemployment to the scarcity of jobs resulting from the current phase of capitalist accumulation were, and still are, totally silenced. Simultaneously, as stated by several researchers ([4], [5]) a 'hidden' objective of this policy was to tackle the problems the schools were unable to deal with: school failure and early school leaving. By assuming this function, the apprenticeship courses became the less prestigious provision in the Portuguese education and training system.

Strongly influenced by the German dual system, the curricular structure of these courses are based on a strong in-job training component, considered by the interviewees as their main comparative advantage. The internships are distributed over the three years of training and correspond to about $40 \%$ of the total hours of training. The weight of the in-job training, when compared with others VET 
provisions, is considered the most relevant advantage of this provision by two of interviewees involved in it.

Opposite to the other VET provisions analyzed in this report, the apprenticeship courses must be approved by the Institute of Employment and Vocational Training (IEFP) and not by the Ministry of Education. The functional dependency from the Ministry of Labor, Solidarity and Social Security confers to these courses a particular place in the national and regional skills system. Firstly, they are mainly located at public training centers or other organizations supervised by the Ministry responsible for this vocational training; secondly, they are not included in the regional offer of VET regional network, supervised by the Mystery of Education were the discussion and definition of the general and VET provisions for each school year takes place.

Over time, the apprenticeship courses have undergone several changes, but their curriculum structure remains almost the same. At present time, these courses are an upper secondary education provision delivering an academic certificate of upper secondary education and a professional certification of EU level 4.

According to the recent law [6] these courses aim both at promoting the young people's initial vocational education and training in order to improve their employability according to the labor market's needs and solving the problem of the early school leavers. Since 2015, they are part of the Youth Guarantee Programme under the scope of the educational measures, and they are expected to contribute to the government benchmark of having $50 \%$ of the students enrolled in upper secondary VET courses, in 2020. However, the lack of public funding for this LLL policy during the last two decades reduced its already small presence in the education and training system. With the present government apprenticeship courses have been elected as one of the most important policies targeted at NEETs. The funding has been reinforced and the pressure to deliver these courses increased, mainly within the training centers responsible for the implementation of active employment policies, known as training centers under the direct management of Institute for Employment and Vocational Training. Furthermore, an advertising campaign has been launched in the media in October 2017. Named Geração Pro (Pro Generation) its main objective is to attract young people to these courses, but no mention is done to NEETs.

When we focus on the aims, objectives and impacts of this policy we find different formulations and approaches according to the different sources and actors. In the law the main objectives are the improvement of young people's employability, and to tackle the problem of the early school leavers. The expected outcomes are: providing early school leavers with vocational qualification and certification, according to the regional and local labor market needs, and reducing the youth unemployment.

For the national policy-makers of the Institute of Employment and Vocational Training, currently, its main objective is to contribute to the reduction of the percentage of NEET since the Institute is responsible for the coordination and implementation of the Youth Guarantee Programme in Portugal. Apprenticeship courses are expected to contribute to reduce the rate of NEET, reaching the EU average by the year 2020 .

The local managers and the street-level professionals involved in this provision have different interpretations of its objectives. For the interviewees from a public training center, with a long experience of apprenticeship courses, the main aims are the academic and the professional qualification of the young people and to secure a better transition from school to work:

To have qualified young people with and academic and a professional qualification and an attitude towards the world of work (....) To have happy citizens with skills, producing and paying taxes. (...) But one more important thing, is a path that will allow young people a better transition, once the course is over, to the labor market (E1).

To prepare these youngsters for a level 4, it's what they have here, give them the possibility, if they want, to continue studies, or through the CET (Technological Specialization Course) or perhaps directly to the university, they give them this capacity, but also if they want to enter the labor market, they can do it directly (E4).

These interviewees omit any reference to the role of this offer in combating school drop-out which throughout its history has contributed to its social devaluation. During the interviews they develop an argumentative strategy that aims at promoting the 'social upgrading' of this provision by presenting it as a first choice path for accomplishing upper secondary education. By using these arguments, they produce an alternative discourse to the hegemonic one. 
For an interviewee from a training center dependent upon Institute of Employment and Vocational Training, the aims of these courses are to qualify the unemployed young adults registered at the employment centers and to attract the NEETs to the qualification process. However, the achievement of the second aim does not appear to be an easy task and it causes a tension between the old and the new assignments of this kind of training centers. These centers are responsible at regional and local levels for the implementation of the active employment policies, mainly vocational training, targeted at unemployed and 'at-risk' populations. During the financial crisis, with the growth of the unemployment rate, they played a significant role in the attempt of reducing unemployment by providing initial and continuing training to unemployed registered at the employment centers. The tension between this traditional assignment and the new one is expressed in the following statement:

There are still a few to identify [the NEET] and within the framework of the Youth Guarantee we have this work to do. We've been doing too little, that's true! But this is a very complex work that requires a lot of our effort, dedication and time, which we often do not have, because every day we have to respond to what is most urgent, which is to give a training answer to those who are already here [unemployed registered at the employment center] (E7).

The recent change in the policy - targeting the apprenticeship courses at the NEETs - along with a greater allocation of financial resources for its implementation had opposite effects on the two regional providers. In the case of the first training center it was an opportunity to increase its initial VET provision and reinforce its presence in the regional skills formation system. In case of the second training center, the policy change increased the work load of the professionals and the pressure to achieve two 'conflicting' aims: to provide education and training to unemployed, and identify NEETs and bring them back to the skills formation system.

It's difficult to assess the results of this LLL policy at regional/local level. Evaluation is a key issue in Portuguese society and there is a general complaint against the lack of evaluation of public policies' results and impacts. Neither of these two training centers is responsible for carrying out any kind of studies on impact of the vocational education and training provision delivered but it doesn't mean they are not done. The studies on impact, which in Portuguese context is synonymous with employability rate, are carried out by national structures on which they depend in order to fulfil the European Structural Funds' requirements. It is worth mentioning that the results of these studies are one of the criteria used for the funding and evaluation of future applications.

In both training centers the national quality departments are responsible for implementing a survey to a national sample of graduates, 6 months or 1 year after completion the training courses. The results obtained are returned to the centers, but their analysis does not contemplate the regional/local level. These are national results that in no way contribute to assessing the effectiveness of the policy at regional level and its impact on the graduates' transition to work, in particular, and their life course, in general. The lack of data makes the interviewees use impressionistic evaluations even if based on their experience and knowledge of the field:

My feeling is that until now, in the past and now, companies are very fond of receiving them, they are permanently open to receive people from this Training Centre (E1).

Professional courses were launched in 1989 and were exclusively delivered by professional schools. They are an upper secondary education provision delivering an academic certification and a professional qualification. Like the apprenticeship courses they also contemplate an internship but its importance in the curricular structure is considerably lower, corresponding to $13.5 \%$ of the total training hours.

After 2004, with the Secondary Education Reform Act, professional courses were introduced in public and private secondary schools. As upper secondary education $\left(12^{\text {th }}\right.$ grade) became compulsory in 2009, professional courses become the most important provision to those students who do not want to pursue an academic education. In Alentejo Litoral professional courses are delivered by both secondary school and professional schools but the second ones are the most important providers of this vocational education and training provision.

The professional courses emerge in a broader set of vocational education and training provisions launched in the 80's, and they were legitimized by discourses demanding the modernization of Portuguese education from the qualification of human resources as a guarantee of economic and social development [7]. Since its launch, professional courses aim at being an alternative to the academic upper secondary education. They do not exclude the possibility of pursuing studies but they are predominantly oriented towards the transition to work, according to the regional labor market 
needs. Similar to apprenticeship courses, professional courses were integrated in the Youth Guarantee Programme under the scope of the educational measures. This inclusion reinforces the importance of another aim, which is implicit in the official documents, but explicit in policy decision makers' public discourses and reproduced by a local manager: to fight early school leaving.

What I think is that vocational education is a great answer for many young people who would never study and drop out of school if there were no professional courses (E5).

The interviewees involved in this policy have some characteristics that give specificity to their statements and that it is important to take into account in this analysis. They are managers of two of the oldest professional schools in Portugal, and have a long experience in these vocational education and training provision. By their nature, these schools are strongly anchored in the regional socioeconomic system, seeking to respond to the needs of skilled workforce. For this reason, both managers consider that the main objective of these courses is to train qualified workforce that matches the needs of the companies and contributes to the economic development of the region:

Let's say that our matrix today, on the Alentejo coast, are two areas of strong economic position and I expect to contribute with qualified workforce to these two areas, right? (E5).

I consider the offer of professional courses a very great asset for the industry and why? Because these industries are extremely complex. (.....) This leads to the need to have technicians with capacity and knowledge and with critical ability to be able to operate these systems in some way, let's say, comfortable, other than just people who have practical knowledge (E6).

By exclusively confining the objectives of these courses to their contribution to the training of skilled workforce, these interviewees are legitimizing one of the most severe criticisms of this policy: its vocationalist drift. In fact, several academics ([8], [9]) consider professional courses as a provision of a technical-instrumental nature oriented towards the production of skilled workers and the management of human resources.

The centrality that the training of skilled workers assumes in the interviewees' discourses is undoubtedly the dominant tonic and reproduces the hegemonic discourse about this provision. For them, the most important aim of this policy is the production of working people capable of responding to the challenges of the 'new spirit of capitalism'. Therefore, they value not only the technical training but also the development of soft skills that integrate the package of qualities required to a 'good worker'. It is within the framework of a technical-managerial conception of this policy that the critical thinking, the autonomy and the responsibility are valued by these interviewees, and not as core skills essential to the integral development of the human being, the participation in society and the exercise of citizenship.

The following statements are paradigmatic examples of this conception of education and its vocacionalist drift:

This model of education makes young people more autonomous, more critical, more responsible and I think this is positive, I think this gives them some baggage to work (E5).

It brings them a critical capacity, it brings them an ability to question innovations, more efficient solutions of operation and maintenance of these industrial systems and units. (E6).

Opposite to what was reported by the apprenticeship courses' local managers, the evaluation studies are compulsory and done locally by each school. The gathered information focus exclusively on graduates' employability rate and it is essential to ensure ESF funding. This type of evaluation based on the graduates' employability rates is widely criticized by the interviewees, although they admit that the values in their schools are higher than those required by the Ministry of Education and the ESF managers: over $50 \%$ of graduates employed. Criticism develops around two key ideas: corporate recruitment management strategies and the specificities of the regional labor market (seasonality and precariousness). In general terms, they challenge the blind use of prescribed indicators by not taking into account the influence that economic factors have on the transition to work, irrespective of the quality of the training provided and its adequacy to business needs.

That's a very relative concept [employability rate], is it not? Because it's not us who create the jobs, it's the companies. And companies sometimes say they need $X$ workers. But when they apply [the graduates], then when they go to hire him/her, they prefer someone who does not have training because they pay less, so that's the problem! (E5). 
The companies, the work they have, it's a work, let's say, it's not continuous in the true meaning of the word. They have some continuous work, but it is, so to speak, perhaps continuous work is the greatest, but then here is a slice of work that is temporary. For example, we already know that $X$, next year, will have work, will have a stop of 3 months or so of the sort. At that time, there are not enough people, not at all. Everyone is employed at that time. If we do an inquiry, for the Ministry, at that time, everybody is employed (E6).

The adult vocational education and training courses were established in 2000 and were very much in line with lifelong learning guidelines of the European Union. These guidelines have stressed the individualization character of forms of provision in education, the valuing of the training component and the relevance of (lifelong) learning. Additionally, training within the link between education and economic development was also stressed. The purpose was to have forms of provision that developed skills, namely hard skills related to traditional school disciplines, according to an innovative curriculum, but also soft skills that had not been traditionally provided by school education and that were relevant for enterprises and existing jobs following neoliberal trends.

These courses are targeted at employed, unemployed and adults more than 18 years old as well as people at risk of social exclusion. As a basic adult education provision, these courses are targeted at all adults that had not achieved compulsory education and did not hold professional qualification, not entailing any kind of gender, race or age requirements. But due to these courses structure, based on a long-term provision (up to 2 and a half or 3 years), mainly unemployed people and those at risk of social exclusion (that were not working full-time) attend these courses. These adults are mainly on social benefits. For this reason, these courses generated a passive admission and/or an apathetic rejection by people in general and in particular by the stakeholders, owing to the fact that these courses were directed at those that were at risk of social exclusion, those that did not have any other kind of public basic education provision to attend.

Adult vocational education and training aim at the generalization of upper secondary education as the lower qualification level of the Portuguese population $(50 \%$ by 2020$)$ and the qualification of the workforce with double certification [10] in order to reduce the unemployment rate.

As with previous interviewees, the objectives set out in the law are not fully reflected in the interviewees' discourses. Effectively none of them refers the raising of the level of qualification of the population as one of the main objectives of this LLL policy. For them, the improvement of individual employability is the main purpose to be reached, as stated by both, a local manager and a street-level professional:

qualify our unemployed people, who are primarily unemployed, in order to give them initial qualifications so that they can be integrated, (...) so that we can try to improve their conditions of employability (E7).

The aim of these courses is to prepare a group of people, to give them, let's say a minimum training to enable them to pursue a professional activity (E8).

The assessment of this LLL policy is made exclusively through information concerning the graduates' employment situation. The data collection follows the same procedure described when we analyzed the apprenticeship courses provided by the training center belonging to the Institute of Employment and Vocational Education and Training. Once again, the fact that the results of the evaluation are national and do not contemplate an analysis at the local level, is criticized by a street-level worker, based on the general argument that the lack of this information can compromise the quality of this LLL policy:

It would be a matter of strategy and I think it made perfect sense. We started by doing career guidance, we train and it was important to see if that training had impacts, to make an evaluation, an analysis. Unfortunately, this work is not done. I think, like many other things in our country, it's a matter of strategy (E9).

\subsection{VET target groups}

The analysis of how do the LLL policies construct their target groups is based on a comparative analysis among their official description, the knowledge produced by social research regarding the young adults' characteristics and the interviewees' social representations.

In several governmental websites, apprenticeship courses are officially targeted at young people aged less than 25 years old, holding an academic certificate of $9^{\text {th }}$ grade and not having accomplished 
upper secondary education. Curiously, in these websites no mention is done to NEET, ESL or unemployed young adults who are effectively this policy's target group, as stated by one interviewee of the training center under the direct management of Institute of Employment and Vocational Training. These two different definitions point to the tension between a 'palliative' measure designed to deal with young people at risk both at the education and the employment systems and the attempt to overcome its stigmatized social representation. As shown by some researches ([4], [9], the social and academic characteristics of the trainees enrolled in this provision has contributed to turn it into the most social disqualified VET provision in Portugal. The large majority of them are low academic achievers, with a school trajectory of failures, and come from working class families. The attempt to carry out a strategy to overcome apprenticeship courses stigmatization is evident in the current official description of the target group in the governmental websites but also in the words of the interviewees from a training center under the participative management of Institute of Employment and Vocational Training. Both strongly deny that this is a second chance provision, aimed at working-class youths with unsuccessful school paths.

I think here is a choice and our teens come by choice and not by being the end of the line. If it was the end of the line we would have teens who failed many times in high school and we would have here many 20 year olds or more and we have teens here that arrive with 15 years, 16 years. That is, they finished the 9th grade and come directly to our courses because it was a choice made by them and because they think it is what it should be. We also have cases of 18, 19 years old who are seeking these courses because they have tried other courses and have seen that it was not what they intended and that they eventually found the job that might be their profession for the rest of their lives. The vast majority we have are very young (E4).

The interviews to local managers and street-work professionals engaged in apprenticeship courses show, on one hand, the existence of two different definitions of the target groups according to the type of provider: the training center under direct management of Institute of Employment and Vocational Training, responsible for the implementation of the public active employment measures, and the other public training center. On the other hand, they indicate the carrying out of a strategy to promote the social upgrading of this LLL policy at a regional level, by the sectorial training center who seems to be able to attract socially and academically different trainees, more similar to the characteristics of the target group advertised in the official websites.

Professional courses are also targeted at young people holding a certificate of $9^{\text {th }}$ grade. Formally, no other characteristics are added to this definition. However, several researches ([11], [12], [13]) point out other attributes of the young people attending this provision. The majority of them come from working class and low middle-class backgrounds. They are low academic achievers, with at least oneyear retention and low scores in PISA.

Boasting a greater social prestige than the apprenticeship courses, but smaller than the prestigious path of access to higher education, professional courses are an alternative path to accomplish compulsory schooling $\left(12^{\text {th }}\right.$ grade) .

The interviewees engaged in professional courses share a common definition of the youngsters enrolled in this policy and very similar to the one pointed out by the researches and the official data of the Ministry of Education [14]. Most of them are 15 years old when they enroll for the first time; less than a half has at least one retention and several come from families 'with difficulties'.

The profile of the student is the student who arrives with the 9th grade of regular education. Therefore, these are the criteria for integrating professional courses. And they enter the 9th year, 15 years. (...) There are many students, there are a large percentage of students that, say, about $30 \%$ of our students have already failed at least once ... so let's say about 60 to $70 \%$ have never failed, but 30 to $40 \%$ certainly have at least one retention (E5).

unstructured families, young people living alone or with siblings or grandparents, economic difficulties (E6). 
They also share the idea that this provision is an alternative to regular upper secondary education pursued by students disenchanted with the 'traditional' education. They agree that they don't get the 'best students', the high achievers, and regret that these young people do not choose these courses. They blame the secondary schools for guiding students with school failure to these courses and dissuading high achievers from choosing them. Based on his experience, one interviewee criticizes school guidance services for dissuading these students to choose professional courses, telling an example:

there is a great deal of pressure on students. There have been cases that we know of who have arrived, who have come to call the parents, saying, 'No, your son should not go there for this reason, for another, I do not know what else. He must stay with us, we are going to prepare him, he finishes the 12th year, goes to university '(E6).

By suggesting that this courses are not for high achievers, regular schools and career and guidance counsellors contribute to perpetuate the idea that vocational education and training courses are a less prestigious provision targeted, exclusively, at those who have not the skills and the competences to attend academic upper secondary education. To those who are labelled by the regular schools as 'little bit dumb' (E6).

In general, all interviewees share a common opinion about the young people's lack of soft skills (responsibility, commitment, autonomy) and life prospects.

What is the problem with these young people? If I can say it this way. There is in fact anything that we sometimes feel in them that ... is a lack of capacity for commitment. To commit to something. And what we feel in the young people who come to us here, many of them already 16, 17, 18 years, therefore already with a certain human formation, is this difficulty of relation with the commitment (E1).

They come with fewer and fewer skills. (...) They are very little responsible; they seem like kids (E6).

I think the new generations, having a more precarious maturity, do not realize that at some point they will be alone, they have to have autonomy. They have to have the same capacity of survival and ability to solve problems from the autonomic point of view. And I do not think the new generations have that ability (E9).

I would identify here the difficulty of setting clear objectives. It's a great common denominator of this audience I guess that's it. There seems to me to be some absence of well-defined objectives, life goals, and I will say that they are drifting here. Because when we do the presentation and when we ask people "what brings you here, what are your projects?" there are usually many difficulties in clearly pointing this or that as an objective (E8).

Based on the deficit approach, commonly mobilized to characterize the public that deviate from the idealized model of white middle-class youth, the interviewees attribute the lack of soft skills to the social context marked by unemployment, poverty, family disruption, emigration....

families are a little bit detached from what their children's school life is. And for different economic reasons, because the parents have to work, because they are looking for a job because they are unemployed, they do not have the time to give their children, to dedicate to their children, and then ... often it is divorces, students are with the grandparents. They live with their grandparents, live with their uncles, let's say that the socio-affective domain weighs heavily today on a large part of the students here in the region (E5).

Despite this negative image, most of the interviewees believe in the positive effects of the LLL policies in which they are involved. They argue that the type of training and guidance provided not only by psychologists but by all other street-level professionals (teachers and trainers), as well as the internships contribute to change behaviors and develop skills, turning young people into totally different persons. 
the psycho-pedagogical monitoring is one of the aspects that we give our students and they have this opportunity to have specific classes in which these things are worked, personal skills, leadership, interpersonal relationships are worked out, all this is worked with them, weekly, fortnightly, as the case may be (E4).

a much more, let's say, much more mature attitude when they finished the course. Mainly, after doing the final work (E6).

The teaching model allows more work to be done at project level, at the autonomous level of development and accountability for their own learning and development of tasks and development of a set of skills, the experience of passing through companies, with some responsibility, assuming some responsibility from a very early stage, I think this gives them some baggage (E5).

\section{CONCLUSIONS}

CPE approach explores how discourses identify problems, though a problematization mechanism, present its solution, truth regimes and social practices [3]. VET provisions were designed to solve one of the most serious problems in the middle 80's: the high rates of youth unemployment. Among the possible explanations for the problem, the hegemonic discourse emphasized only one: the lack of young people's skills. All the alternative explanations were silenced, namely those emphasizing the shortage of jobs due to the structural changes of capitalism. Based on the Human Capital Theory, the only possible solution was to equip young people with the skills needed in the labor market. Furthermore, the integration of Portugal into EEC/EU allowed access to ESF funding which was intended exclusively for VET provisions.

This resonant discourse was accompanied by a less hegemonic one that emphasized the democratization of school success. The educational system was dealing with very high rates of school failure and drop-out. VET provisions more oriented towards more practical teaching were expected to attract low achievers and early school leavers and contribute to their school success. However, an unexpected effect occurred. The democratization of school success has brought with it the social disqualification of these educational offers. By presenting themselves as palliative measures to combat school failure and drop-out, they become ghettos for a population disenchanted with traditional academic education, from which the high achievers move away.

In the 90's a variation mechanism took place due to semiotic changes. Employability and inclusion became categories of political action replacing those of unemployment and democratization. Social exclusion has become a European priority since 1989, when the European Council of Ministers approves the creation of the Observatory to combat social exclusion. A second step in the diffusion of social exclusion as a hegemonic category to take account of social and economic transformations in European societies and to guide public action takes place in 1993 with the launching of the Green Paper on European social policy. Employability, for its part, gains visibility with the publication of the Green Paper on competitiveness and employment and becomes one of the main guidelines for education and training policies and for active employment policies in the European area. The Portuguese policy discourses adopt these semiotic categories and the main objectives of VET provisions became to promote social inclusion and employability. Recent material changes such as the increase of compulsory education, and the financial crisis contribute to institutionalization of this resonant discourse and its integration in a consensual compromise.

\section{REFERENCES}

[1] B. Jessop, "Critical semiotic analysis and cultural political economy", Critical Discourse Studies, vol. 1, no. 2, pp. 159-174, 2004.

[2] B. Jessop, "Cultural political economy and critical policy studies". Critical Policy Studies, vol. 3, no. 3-4, pp. 336-356, 2010. 
[3] N. L. Sum, \& B. Jessop, Towards a Cultural Political Economy: Putting Culture in Its Place. Cheltenham: Edward Elgar Publishing, 2013.

[4] R. Grácio, Política educativa como tecnologia social: as reformas do ensino técnico de 1948 e 1983. Lisboa: Livros Horizonte, 1991.

[5] N. Alves (coord), A. J. Almeida, M. Fontoura, P. Alves, Educação e Formação: análise comparativa dos sub-sistemas de qualificação profissional de nível III. Lisboa: IEFP, 2001.

[6] Ministerial Order no. 1497/2008 of $19^{\text {th }}$ December.

[7] Decree-Law no. 26/1989 of $21^{\text {th }}$ January.

[8] F. Antunes, Políticas Educativas Nacionais e Globalização. Novas Instituições e Processos Educativos. O Subsistema das Escolas Profissionais em Portugal (1987/1998). Braga: Centro de Investigação em Educação do Instituto de Educação e Psicologia da Universidade do Minho, 2004.

[9] N. Alves, "Políticas de educação-formação para jovens: tensões e contradições". Perspectiva, vol. 26, no.1, pp. 209-230, 2008.

[10] Law no. 230/2008 of $7^{\text {th }}$ of March.

[11] L. Pardal, A. Ventura, C. Dias, O ensino técnico em Portugal. Aveiro: Universidade de Aveiro, 2003.

[12] P. M. Mendes, Estudantes do ensino secundário profissional: origem social, escolhas escolares e expectativas. Lisboa: ISCTE Instituto Universitário de Lisboa, 2009.

[13] F. L. Machado (coord), D. Nóvoas, S. Fernandes, T. Pereira, Estudantes no Pós-Secundário. Retrieved from http://alturl.com/tj7ks

[14] DGEEC, Relatório de escola do questionário estudantes à entrada do Secundário 2013/14. Lisboa: DGEEC, 2015. 